\title{
Islam, Hijab and Young Shia Muslim Canadian Women's Discursive Constructions of Physical Activity
}

\author{
Nisara Jiwani \\ University of Ottawa \\ Geneviève Rail \\ Concordia University
}

\begin{abstract}
This article focuses on the results of a study exploring young Shia Muslim Canadian women's discursive constructions of physical activity in relation to Islam and the Hijab. The aims of the study were primarily informed by feminist poststructuralist and postcolonial theories. Poststructuralist discourse analysis was used to analyze the transcripts of conversations with 10 young Hijab-wearing Shia Muslim Canadian women. The results show that the participants discursively constructed physical activity in terms of being physically active (involved in fitness activities rather than sport), feeling good about themselves (i.e., being physically and mentally healthy), and losing weight or remaining "not fat." The participants mentioned that they would choose Islam over physical activity if they had to make a choice between the two. Participants strongly resisted the Islamophobic discourse present in Canada, and appropriated an intersectional discourse that legitimates their refusal to choose between their right to religious freedom and their right to physical activity.
\end{abstract}

Cet article porte sur les jeunes femmes canadiennes de religion chiite et sur leurs constructions discursives de l'activité physique en lien avec l'Islam et le port du Hijab. L'étude a été réalisée à partir d'un cadre théorique poststructuraliste et postcolonial. Une analyse poststructuraliste du discours a été utilisée pour investiguer les transcriptions de conversations avec 10 jeunes canadiennes de religion chiite qui portent le foulard. Les résultats sont à l'effet que les participantes ont construit discursivement l'activité physique en termes d'être physiquement actives (elles s'intéressent aux activités de conditionnement physique plutôt qu'au sport), de se sentir bien (i.e., être en santé aux plans mental et physique), et de perdre du poids ou de maintenir leur minceur. Les participantes ont mentionné qu'elles choisiraient l'Islam plutôt que l'activité physique si elles devaient faire un choix. Elles ont démontré une forte résistance au discours islamophobe qui prévaut au Canada et ont approprié un discours qui reconnaît simultanément les

Jiwani is with the University of Ottawa-Human Kinetics, Ottawa Ontario, Canada. Rail is with Concordia University—Simone de Beauvoir Institute, Montreal, Quebec, Canada. 
divers systèmes d'oppression (patriarcat, racisme, sexisme). Ce dernier discours est utilisé pour légitimer leur refus de choisir entre leur droit à la liberté religieuse et leur droit à l'activité physique.

In recent years, there has been a series of much mediated incidents regarding young Muslim Canadian women and their sporting experiences. At the center of the controversies, we often find the much-maligned Hijab. In a number of cases, young women in Canada and elsewhere have been told to either remove the Hijab or remove themselves from the game ("FIFA ban," 2010; "Hijab a safety risk," 2007; "More athletes," 2007). While much has been written in mainstream media about Hijab-wearing women and sport, in-depth knowledge of this topic is inexistent as very few sport scholars have endeavored to research this issue.

At first glance, young Muslim Canadian women interested in physical activity or sport seem to confront a multifaceted problem. For many of them and especially those who wear the religious headgear, the constant (re)negotiations of a "safe" space to practice physical activity coupled with the experiences associated with being a Muslim woman in Canada seem difficult to juggle. To date, however, little is known about such negotiations and experiences. Early research on race/ethnicity and sport has been criticized for being ethnocentric (Fleming, 1994), for homogenizing Muslim women, and for contributing to rather than dispelling the stereotypes regarding Muslim women's oppression and lack of physical activity (Walseth, 2006).

Given the importance of filling the gaps in the literature particularly for institutions and communities intent on improving Muslim women's physical activity experiences, this article aims to further our understanding of young (i.e., between 18 and 28 years of age) Muslim Canadian women's discursive constructions of physical activity. In addition, we explore (a) their reasons for partaking (or not) in physical activity; (b) their views of physical activity in relation to Islam and the Hijab; and (c) their relation to dominant social discourses on gender, culture and religion.

\section{Sport Studies and Muslim Women}

Within sport scholarship, a few researchers have contributed to the body of literature on Muslim women by helping to dispel stereotypes and furthering our understanding of the barriers they face within sports and physical activity (Carrington, Chivers \& Williams, 1987; Dagkas \& Benn, 2006; Fleming 1994; Nakamura, 2002; Sfeir, 1985; Tess, 2006; Walseth; 2006; Walseth \& Fasting, 2003; Wray, 2001). Early research suggests that due to gender differences, Muslim girls face more challenges than Muslim boys in the context of physical activity. According to Carrington and his colleagues (1987), these challenges are due to religious and cultural traditions that assign men and women particular roles, and institute dress codes that restrict access to or movement within physical education classes. While some research (De Knop, Theeboom, Wittock \& DeMartelaer, 1996; Fleming, 1994) has demonstrated that the Muslim youth place low value on physical activity, Thompson (1990) has argued that Muslim women are more interested in getting their children involved in physical activity than getting involved themselves.

Some studies have hinted that the Islamic religion furthers negative attitudes toward physical activity although others have illustrated Islam's encouragement of physical activity for all Muslims, including women (Khan, 2002; Walseth \& 
Fasting, 2003; Zaman 1997). In their study of Egyptian Muslim women, Walseth and Fasting (2003) have suggested that those who support the fundamentalist interpretation of Islam strongly agreed with women's participation in physical activity. However, the lack of appropriate facilities and opportunities as well as negative associations with the Hijab have been shown to constitute barriers to the point that many Muslim women tend to restrict their participation in physical activity or to restrict it to spaces exclusive to their cultural and religious groups (De Knop et al., 1996; Nakamura, 2002; Taylor \& Toohey, 2002; Tirone, 2000; Zaman, 1997).

Walseth (2006) has documented how young Muslim women's ethnic and religious identities create specific challenges to physical activity as the latter is contrasted to a "respectable femininity." Similarly, Vertinsky, Batth and Naidu (1996) have examined participation in physical activity and noted that families tend to push young women toward "feminine" activities (i.e., non-contact activities such as badminton and dancing) that are seen to uphold the values of modesty and conventional femininity dear to traditional Indian culture. Those who challenged normative femininity experienced disapproval or harassment and sanctions ranged from being the object of gossip or being described as "too Western" to direct harassment leading to disengagement from "improper" physical activities (Walseth, 2006).

Muslim women's self-identified "culture" is produced through family connections with the "homeland" and is part of their identities (Kaiser \& Rasminsky, 2007). Scholars have shown how family life and values are still highly respected within many immigrant communities (Basit, 1997; Tess, 2006). Dagkas and Benn's (2006) research has suggested that Greek and British Muslim women hold positive views toward physical activity but are restricted in their participation due to their communities' requirements in terms of dress codes, gender segregation, and fasting during the month of Ramadan. Family expectations seem to impact on young women's choice of physical activity (Tess, 2006). At the same time, many physically active young women receive positive encouragement from their families and enjoy their parents' active role as companions, spectators for events and games, and providers of transportation to and from venues (Tirone, 2000).

Away from home or their community, when young women are expected to partake in coeducational activities or wear revealing clothing, they have been found to lose interest (Nakamura, 2002; Vertinsky et al., 1996). Vertinsky and her colleagues (1996) have also suggested that the choice not to participate can be interpreted by recreation providers as refusal to integrate or lack of physical ability, which only reinforce stereotypes. Guerin, Diiriye, Corrigan and Guerin (2003) have explored the barriers to physical activity for Muslim women of Somali origin and found that culturally — and religiously — appropriate physical activity opportunities benefit both these women and the larger community. They have noticed the benefits of positive social interactions, including those with other women who are neither Islamic nor from Somalia. Most importantly, they found that the Muslim women's self identification of their needs was a key to successful physical activity programs.

Focusing on young South-Asian Canadian women's discursive constructions of health, George and Rail (2006) found that they equated health with "looking good" and that physical activity was seen as a strategy to reach this goal. These authors have also drawn attention to physical activity as a way in which these young women subvert stereotypes emphasizing the passivity, docility, and uncleanliness of women of South-Asian background. At the same time, they have shown how 
these young women locate themselves, as subjects, within dominant discourses on conventional (white, bourgeois) femininity and heteronormativity, and how such positioning leads to physical activity but also dubious practices (e.g., dieting, electrolysis, bleaching) to "look good" and thus "be healthy." In a number of ways, these women were not that different from other women who try to conform to the ideal identified by Markula (1995, p. 424): "firm but shapely, fit but sexy and strong but thin." Markula has noted that while women who participate in aerobics classes often promulgate mainstream dominant discourses of femininity and want to improve their appearance, at the same time they cite other important reasons for partaking in physical activity: enjoying a safe space, enjoying physical activity, and experiencing increased energy to carry out daily work.

In brief, the literature on Muslim women and physical activity has generally focused on issues of barriers and solutions for access. Religious and cultural practices, which differ quite significantly between Muslim sects and communities (a fact rarely acknowledged by authors who tend to homogenize Muslim women), have been the object of limited research in relation to physical activity. Many questions are thus left unanswered and our paper constitutes a modest attempt to contribute to knowledge by focusing on young Muslim Canadian women's discursive constructions of physical activity and their relation to culture, religion and the Hijab. Our paper is primarily informed by feminist poststructuralist and postcolonial theories and concepts, to which we now turn.

\section{Feminist Poststructuralist and Postcolonial Perspective}

In our research we chose to work within a feminist poststructuralist and postcolonial perspective (Bhabha, 1994; Brah, 1996; Foucault, 1972, 1977; Rail, 2002; Said, 1978; Spivak 1988; Weedon, 1987, 1999) which informed the questions we asked, the method we chose, and the ways in which we interpreted our participants' narratives.

Feminist poststructuralist orientation provided us with the concepts to understand how gendered power relations are reproduced and contested (Weedon, 1987). Foucault's concept of discourse was particularly useful. For Foucault (1972), discourse is comprised of knowledge, social practices, and power relations and it is enabled by many social and institutional sources. Discourse is always part of the operation of power wherein it constructs, defines, and produces objects of knowledge. For Foucault, the exercise of power cannot be possible without discourse and the production of "truth" cannot occur without exercising power. The concept of discourse is tied to another key poststructuralist concept: subjectivity (Butler, 1997). According to Butler (1997), the subject takes form from language, gestures, speech acts, reflective processes, and other performative behavior. But this subjectivity is constituted through the (gendered, ethnicized, and racialized) discourses to which the subject has access. In addition to mapping the discourses to which young Muslim Canadian women have access when they construct their meanings of physical activity, we investigate how they position themselves in relation to these discourses, how they constitute their subjectivity within such discourses, and how they become subjects of such discourses by 
"subjecting" themselves to their meanings and power (Hall, 2001). The appropriation of dominant discourses speaks in many ways to Foucault's (1977) concept of normalization. Normalization involves the construction of an idealized norm of conduct and then a more or less formal system of rewards or punishment for conforming to or deviating from this ideal. Therefore, the gender, religious, and cultural norms, and their impact on young Muslim women's discursive constructions of their reality deserved investigation. Finally, in feminist poststructuralist theory, language provides structures through which subjects construct themselves as well as reality around them (Weedon, 1999). Discursive constructions of reality are thus always historically and culturally specific, and meaning can never be static. For example, the word "Islam" itself means peace, and to Muslims it may be understood as such. However, in Western context, Islam is coupled with fear, Jihad, and terrorism. Thus, as Loomba suggests, "language is not a nomenclature or way of naming things that already exists, but a system of signs whose meaning is relational" (1998, p. 35).

Our feminist postcolonialist orientation informed by the writings of Said (1978), Spivak (1988), and Bhabha (1994) and provides us with understandings of identity that move away from static representations to speak to the competing discourses within which the individual is positioned. In such perspective, ethnicity is best understood as a dynamic, evolving property of both individual identity and group organization. The construction of ethnic identity and culture is the result of both structure and agency as ethnic groups continuously (re)shape their self-definition and culture (Nagel, 1994). Feminist postcolonialism also allows us to understand the mechanics of women's oppression through the hierarchy of gender and the strength of colonialism (Brah, 1996; Williams \& Chrisman, 1994) and provides us with the concept of the "Other" (the exotic, the unknown, the oppressed, the marginalized women). Spivak (1988) has notably written about the representation of the "Other" in art, philosophy, media, and theory, and how it "speaks for" the Other without actually understanding who the Other is. Spivak has explained the tendency to homogenize the experiences of the Other. Said (1978) looked at colonial legacy, colonial discourse, and the ways in which the West constructed the "Orient" as different and exotic. Said and other authors have argued that colonialism has created damaging political, psychological, and moral effects on the colonized subject (Fanon, 1967; Loomba, 1998). Such effects are still being felt across many nations: people may try to break free of colonialist ideas within their homelands or confront them as migrants who now reside in Western countries (Handa, 2003). For instance, through the course of dislocation, migration, and integration into the West, Oriental Muslims have had to redefine their identity within the host society. Some authors have shown how the representation of Islam in a Western context has had major implications for the Muslim diaspora (Brah, 1996; Said, 1978) which may be understood in relation to displacement and migration to a new country while still acknowledging "the old country," its customs, languages, and traditions (Handa, 2003). Brah has also introduced the concept of diasporic space to speak specifically to "the point at which boundaries of inclusion and exclusion, of belonging and otherness, of 'us' and 'them' are contested" (1996, p. 181). In relation to diasporic spaces, she has written about the balancing act immigrants must face: the pull to assimilate to Western society and the desire to maintain their cultural identity. 


\section{Feminist Methods and Poststructuralist Discourse Analysis}

Our feminist poststructuralist and postcolonial framework has led us to favor particular methodological strategies. As researchers, we were interested not only in what young women had to say about physical activity, Islam and the Hijab, but also in how they constructed such reality within available discourses and how, through language, they constructed themselves as subjects. For our data collection, we borrowed elements from both feminist ethnography and postmodern interview research (Gubrium \& Holstein, 2003; Reinharz; 1992). We analyzed our empirical material by using thematic and poststructuralist discourse analyses (Rail, 2009).

Our study involved informal conversations with 10 Shia Muslim Canadian women between the ages of 20-26 years. These women were recruited within the Shia Muslim communities in Ottawa and Toronto via a snowball technique. In discussions about our sample, we were struck by the problematic tendency of homogenizing Muslim women and acutely aware of the impossibility of having a sample that "made sense." We were confronted with the multiple interpretations of the Islamic faith, the incredible number of sects (for example, within our study four identified as Shia-Ithnashari, three as Shia-Bohras, two as Shia-Zaidiyyah and one as simply Shia) involved and the endless religious variations brought by diasporic spaces (i.e., Shia Muslims may identify with various homelands on different continents). Given the first author's role as interviewer/conversationist, her connections to Shia Muslim communities (she is Shia Muslim herself) and her ethnic identity (she has ancestral ties to India), we decided to select participants who were young Hijab-wearing Shia Muslim Canadian women who had ancestral ties to India. This is not to say that the first author could be seen simply as an insider (and contrasted to the second author: a white, atheist, and queer "Québécoise"). Indeed, the first author often felt as an outsider because of her own sect within Islam, the manner in which she practices her religion, and her personal choice not to wear the Hijab. As Canadian women who have pursued our education in a Western context, revealing the experiences of some Shia Muslim women can be seen as an act of intellectual colonialism (Smith, 1999; Vertinsky, Batth, \& Naidu, 1996). Yet, as some suggest (Roman, 1993; Spivak, 1988), taking the risk of speaking with rather than for these women may be better than the risk of silence. We did take this risk but emphasized, throughout our study, the importance of a nonexploitative relationship between ourselves and the participants (Ahmad, 2003; Seibold, 2002).

We developed a conversational model borrowing from Kvale (1996) and from Gubrium and Holstein (2003). The conversation, as a research instrument, was designed to give much room for interactions and involved a collaborative interchange of views between two persons (a participant and the first author) conversing about themes of mutual interests. Participants could choose the direction of the conversation although four themes were preidentified to help focus the conversations: constructions of physical activity, sources of such discursive constructions, integration of physical activity and Hijab in day-to-day life, and physical activity and the Hijab. The length of each conversation varied between 1 and $2 \mathrm{hr}$. Conversations were recorded and transcribed verbatim.

For the analysis of the conversations, first, we completed a thematic analysis, which consisted of coding and regrouping fragments of narratives into "themes" 
(what participants said) based on their semantic affinity (Rail, 2009). Narratives were analyzed vertically (i.e., one transcript after another) and then transversally to look for similarities and differences between participants. Second, we submitted the narratives to a poststructuralist discourse analysis (Lupton, 1992; Rail, 2009; Weedon, 1997). This analysis allowed us to further explore the narratives to document how participants used language (how they said things); how they positioned and constructed themselves within dominant and/or alternative discourses related to physical activity, gender, Islam and the Hijab; and finally how they subjected themselves to the rules, meanings, and power of such discourses. Generally, this analysis helped us to locate the "truths" shaping the participants' understandings and constructions of their social realm.

\section{Discursive Constructions of Physical Activity}

The results of our thematic and discourse analyses are presented and discussed in the next subsections. We first discuss how young Shia Muslim Canadian women discursively construct physical activity, then we look at the meaning of place in relation to their physical activity practices and finally, we explore how physical activity is traversed by Islam and the wearing of the Hijab.

\section{Constructions of Physical Activity}

In our study, the conversations with the young Shia Muslim Canadian women began with a question about what physical activity meant to them. Five main themes emerged from such conversations. To the young women, physical activity means (in order of importance in the narratives): (a) being physically active; (b) feeling good; (c) losing weight; and (d) being involved in "a chore."

With regards to the first theme, we note that most young women's constructions of physical activity are closely linked to gendered ideas promoted by many mainstream media outlets as well as health and physical activity classes (Rail, 2009). The participants' narratives most often suggest that being physically active can be equated with "moving," "fitness," "going to the gym" and "working out." Only a small number of participants discuss physical activity in connection to sport ("being athletic," "doing sports"); clearly, the preferred reading of physical activity involves fitness and going to the gym. This important difference points to the young women's appropriation of a dominant discourse about sport and physical activity: a gendered discourse that stipulates that sport has more meaning to men than women and that assumes that physical activity can be ideally marketed to women when it rearticulates a conventional discourse of femininity. This finding coincides with Markula's (1995) suggestion that a majority of women engage in activities such as exercise and dieting to resemble the narrowly defined beauty ideal within Western culture. Certain forms of physical activity and the manner in which young women speak about them clearly suggest the articulation of a dominant discourse on conventional femininity and the responsibility women have to take for achieving its standards (Markula, 1995). Our finding also concurs with that of George and Rail (2006) whose young South-Asian Canadian women participants foremost equated notions of "health" with "looking great" and "feeling sexy." Through conventional discourses about femininity, the young Shia Muslim women in our study construct 
themselves as "normalized" subjects: they offer no resistance to the noted gender differences in relation to physical activity and sport, and they engage in a consumer lifestyle that often involves fitness services and products.

In the second theme, the young women construct physical activity in relation to a bodily feeling ("feeling good in your body"), a "psychological" feeling ("feeling self-confidence") or both ("feeling good, feeling healthy"). A few women use a holistic approach to suggest that "feeling good" is linked to mental and physical wellbeing. For instance, Sarah's meaning of physical activity encompasses this description: "mental health, physical health and a lot of the two are very linked together. It's important for energy and just personal balance in your lifestyle." Such constructions were echoed by George and Rail (2006) who found that, for a majority of the young women in their study, fitness or physical activity was not associated with movement, pleasure, fresh air, leisure, down time, freedom, social encounters or friendships as much as to "health." Similarly, Dagkas and Benn (2006) as well as Guerin and colleagues (2003b) found that overall, individuals were quick to recognize the health benefits of physical activity. In all cases, it is easy to note the strong presence of a dominant neoliberal discourse of individual responsibility for one's health and its direct link to the notion of self-responsibility for one's lifestyle (Rail, Holmes \& Murray, 2010). The young women from our study do associate physical activity to positive feelings and self-confidence. At the same time, they construct themselves as "healthy" subjects by recuperating elements of a healthist discourse (Crawford, 1980; Rail, 2009) that tends to focus on self-responsibility for health, to obfuscate social, occupational or environmental determinants of health, and to blame individuals who fail to "perform" health.

With respect to the third and fourth themes, some of the young women link physical activity to losing weight and a few see physical activity as a "chore" or an "unpleasant task." Markula (1995) suggests that women accept "disciplining" their bodies since they are lead to believe that after achieving an ideal body size, their lives will become better. Guerin, Abdi and Guerin (2003) also gave some indication that Somali women in New Zealand were concerned about weight gain and George and Rail (2006) found that South-Asian Canadian women were involved in physical activity mostly as a way to ensure that they would not become overweight or "fat." Like their South-Asian Canadian counterparts, the young women in our study tend to reproduce dominant messages about fat bodies. For some, it is about not being "fat" or "chubby" while for others it is more about maintaining a certain body size or weight. The following excerpt illustrates this concern:

It's actually been very important to me in life. I've always been the fat kid so I don't blame myself. I blame genetics. I got to eat whatever I wanted and things like that. But, I think I realized that, when I was 16, people were taking me for 26 or 27 and it kind of really hit me hard. And so, from then on, when I started university, my best excuse was that I was paying this gym fee out of my tuition that I don't use so why not take advantage of it? (Farah)

For some other participants, the concern is not so much about losing weight, but about remaining thin and fit. Laila's narrative is a telling example:

I think [the message regarding obesity] reinforces the importance of physical activity. I mean, the [obesity] rates are alarming in health. As a future health 
professional, I know what the impact will be on the population, on the health care system. But to me, it's just kind of... It reinforces the importance of physical activity to me. It makes me feel good about going to the gym. It's like, "O.K. I don't want to be a part of that statistic."

Within the narratives more generally, constant links are made between physical activity and staying in shape or losing weight. Physical activity is constructed less as something that is good or positive in and of itself and more as a means to obtain an ideal body shape, to maintain or lose weight, to achieve a balanced lifestyle or to be healthy. In the last few years, there has been an explosion of messages suggesting the rapid acceleration of obesity rates in Canada and, more generally, in the Western world. Many observers have recognized a mixture of science and consumer culture forming a dominant obesity discourse that problematically links weight to health and that presents obesity in terms of moral and economic costs to society (Gard \& Wright, 2005). Obese bodies are constructed as lazy and expensive bodies that should be submitted to expert investigation and monitoring (Wright \& Harwood, 2009). The young Shia Muslim women in our study certainly construct themselves as subjects within such dominant obesity discourse. They construct themselves as individuals who are subject to its proposed regulations and controls, particularly those occurring via physical activity.

\section{Place of Physical Activity}

Analysis of the conversations with the young Shia Muslim Canadian women yielded three major themes in relation to the place of physical activity: (a) physical activity places are not very present within Shia Muslim communities; (b) when physical activity places are provided within Shia Muslim communities, physical activity is rarely the main purpose; and (c) "proper" physical activity places are rarely present within the larger Canadian community.

For the first theme, some participants discuss the location of their physical activity practices and note that it is rarely within their Shia Muslim community. They explain this by speaking of generational differences within their community: they suggest that the younger generation is more physically active than the older one who is not that interested in physical activity or setting up places for it. The following excerpt from Nisara's conversation with Laila speaks to this issue:

I don't get the impression that they're physically active. I don't think they're against physical activity, but they're just not. ... They're another generation and, to them, it's all about... Uhmm. They're more religious than I am. Well the last generation, I' $m$ sure they're all immigrants, like the mothers, they grew up in Africa, in East Africa. Physical activity wasn't something girls did. I don't know. It's physical activity, you guys all do it, all ages kind of thing but back home, it was: "What do you mean by physical activity?" Like go to the gym, play volleyball: "it's what the kids do." They're just, they're too busy for physical activity; it's not something that's in their mind.

As Laila explains, physical activity is not a preoccupation for older generations. It seems to be perceived by them (and, to a certain extent, by Laila when she adopts a different subject position to say "you guys all do it") as something 
typically reserved for North Americans, something not typically associated with the culture of Shia Muslim immigrants. In addition to generational differences, many participants alluded to the lack of place for physical activity in their community when discussing the importance of religion:

For the community, there are a lot of things that are important, I mean, you can't really say one thing. It's just priorities. It's like, I don't remember in Islamic functions anyone saying, like the Imams saying, "oh, go workout and be fit and eat a healthy diet" [laughs]. You know? I just. . . It doesn't happen. It's more like: "be well mannered, be good to people, don't swear, don't steal." It's more about the manners and the intangible things than about physical activity. (Samia)

As Samia points out, religious community leaders are not focused on physical activity as much as they are on the basic aspects of religion. Samia is quick to point out, however, that Islam is no stranger to the idea of taking care of one's body:

I know in Islam you're supposed to take care of your body and your health, and you're supposed to be skilled and take care of your body and be physically fit. But they don't really commit to that that much. If you didn't read it or look for it, you probably wouldn't have heard of it. So, I think that, sometimes, culture goes over religion and overshadows it.

While the participants recognize that physical activity places and programs are limited within their own communities, they are not upset at community leaders for this shortage. Rather, they seem to accept the notion that, for the community, religion is more important than physical activity and, furthermore, that those in the community who are in a position of power may come from a different generation and a different cultural environment within which physical activity is nonexistent or reserved for either children or boys. This thinking is not unlike that found by De Knop and colleagues (1996) who note that while younger Muslim women who have been brought up in the West often have a "modern religious attitude," they still uphold traditional values. De Knop and colleagues (1995) as well as Fleming and Khan (1994) also found that young Muslims express positive attitudes toward sport and physical activity but routinely give religion a higher priority. All such views are echoed by the young Shia Muslim Canadian women. What is noteworthy is that in discursively constructing "appropriate" physical activity places for them, young Shia Muslim Canadian women make no appeal to a gender equity discourse that would make evident the fact that, within their communities, boys get more opportunities than girls. Rather, the participants construct themselves as "normalized" subjects within a conventional discourse on gender that underlies the acceptance of whatever is allotted to women in terms of physical activity. The young women in our study also appropriate a dominant religious discourse on women and physical activity - a view within which religion is put above physical activity, and particularly so for young women.

The second theme emerging from the discussions on the place of physical activity relates to the young Shia Muslim women's suggestions that while physical activity places do exist in the community, they seem to have implicit functions that are not directly related to physical activity. For instance, physical activity places 
and activities may be offered but the underlying motivation has to do with (highly heterosexualized) "socializing" factors. For example, such places may allow younger boys and girls to see each other, they may offer an opportunity for mothers to "check out" boys for their girls or they may satisfy parents who want their girls to lose weight. The following narrative illustrates these elements:

It's just to get the community together. It's not for physical activity purposes or promotion of health and physical activity: it's more getting communities together, you know. Like, this was across Jamats [communities], and so that's important cause you're meeting others. Like, say you go to New York and there are aunties there and they're watching your demeanor and they have sons. You know, that's more for that kind of thing too: meeting people. Although, like, the girls can go watch the guys, right? It's just guys can't come watch girls cause there's other girls there that are non-Mahrams [non-family members] to them so, um, when games are over for girls, a lot of girls went to the guys. (Fatima)

The third theme that emerged from our analysis focused on the lack of "proper" physical activity places outside Shia Muslim communities. The participants were unanimous in their assessment that women-only facilities are rarely available in the larger Canadian society and that, consequently, their own community has to provide them. In that regard, consider the following statement from Karima:

Well, because they're not offered in, well, they're not offered enough in the regular society so we have to provide them for ourselves. It's, like, we have to be self-dependant kind of thing and if it's not provided then we have our own facilities. Sometimes we meet up either at somebody else's house or we just play games or just do again, like, yoga or anything that we are doing in our environment, like a women-only environment that we are not gonna find outside or elsewhere.

Nakamura (2002), Taylor and Toohey (2002) as well as Walseth and Fasting (2003) have similarly reported that Muslim women experience a marginalization of their recreation needs when physical activity places are designed to cater to the general population. Mainstream places translate, for our participants, in the idea that minorities are expected to conform to the norms of dominant society (Yilmaz, 2000): mix with men and/or wear the Hijab, the Niqab (a veil which covers the face but leaves the eyes and part of the forehead visible), the Shalwar Kameez (a long shirt worn over pants) and/or the bodykini (a two piece swimsuit which comprises a shirt with an attached headpiece and separate pants).

In the young Shia Muslim women's narratives on the place of physical activity, the overall discursive tenor is one of citizenship and entitlement (e.g., to womenonly spaces, to the larger society's acceptance of their religious identity and how it translates in what they wear). For a number of them, such entitlement is viewed not necessarily as a goal in and of itself, but as a means of engagement in, and integration to, the larger society. While they construct themselves as Canadian subjects who deserve the same benefits and rewards as those of other citizens, the discourse of entitlement they reproduce is rather discreet. Indeed, these women recognize that opportunities are currently limited in the larger Canadian society and that they can accommodate to this state of affairs. Furthermore, focusing on physical 
activity places within their own communities is an interesting strategy for three main reasons: they feel less embarrassed to do physical activity while wearing the Hijab, they feel safer as they can participate under the watchful eye of community members, and they can take part in the networks and social encounters for which physical activity places seem designed, at least in part. Bhopal (1997) provides a similar explanation in her study of British South-Asian women who very much value family traditions and community connections.

Other authors have found that parents often deter their children from joining groups outside of the "ethnic" community and are less supportive of participation in "outside" physical activity programs (Tess, 2006; Tirone, 2000). In contrast, most participants in our study suggest that their parents are supportive of their participation in physical activity in places both inside and outside the community, as long as rules pertaining to the Islamic faith are respected (e.g., sex-segregation, wearing the Hijab).

\section{Physical Activity, Religion and the Hijab}

Beyond the issue of place, the young Shia Muslim Canadian women discursively constructed physical activity in reference to the Hijab and to religion in general. The major themes emerging from the participants' narratives are: (a) religion's precedence over physical activity; (b) physical activity as a means to become a better Muslim; and (c) the difficult combination of physical activity and the Hijab.

With regards to the first theme, the narratives point quite clearly to religion's greater importance when compared with physical activity. At first glance, this appears like a nonissue since people in most religions do not have to choose between religion and physical activity. But our young Shia Muslim participants often felt confronted with such choice when trying to integrate physical activity places outside of their Shia Muslim communities. They agree that they would choose Islam over physical activity if they had to choose:

To me, it was very... Like my religion comes before sports or, like, sports is so important but religion is, like, it's RELIGION! Like you can't compromise that just because, you know? . . . It depends on what your priorities are and if I had to choose, and it was a life and death choice between sports and religion? Sorry sports, but religion is there. (Fatima)

Our religion is very important and, to an extent, if I had to stay at home just because I wore the Hijab, I would . . . I find that religion is what straightens your afterlife but what am I going to do with physical activity if I'm not going to have a good afterlife? So yes, definitely, I wouldn't even think about it twice and I would always choose my religion upon anything else. (Sana)

While the issue of choice is very present in the narratives, all participants confide that they can and do combine physical activity and religion. They construct their (however temporary and fluid) subjectivities and positions as "good" subjects who adhere to the practices of the Islamic faith. A majority feel that neither the Islamic religion nor wearing the Hijab are barriers to participating in physical activity and some actually feel that participating in physical activity makes them better Muslims, which was the second theme emerging from the women's narratives. This excerpt from Samia is a good illustration of many of the young women's perspective on this: 
As a Muslim, I'm always thinking about how I can improve myself and better myself and that's part of it. And being successful, educated, and there's a physical side, like, there's my self physically. I try to be active, I try to be, uh, well rounded, you know, play sports. I know how to play squash; I know how to play basketball. So, it's kind of like, trying to be a better Muslim.

The participants recite a discourse dominant in their own communities; a discourse that presents a relatively progressive interpretation of the Quran in the sense of encouraging a variety of physical activities for young men and women. This has to be contrasted to particular sects within the larger Shia Muslim diaspora. Indeed, because of their sexual connotations, various sects prohibit certain types of physical activity (e.g., dancing) or certain types of music (e.g., those with suggestive lyrical content) accompanying physical activity (Nakamura, 2002). Participating in physical activity (and particularly working-out at the gym) enabled the women in our study to construct themselves as modern (i.e., participating in modern bodily practices) Muslim (i.e., practicing their Islamic faith and wearing the Hijab) subjects (i.e., occupants of discursive "sites" but also agents). While colonial and neo-colonial discourses represent veiled women as passive, oppressed, and devoid of subjectivity and agency (Mohanty, 2004), our participants rewrite the trope of the veiled woman into one involving an active postcolonial subject capable of affirmation. In a Western context, their simple participation in physical activity has radical implications in terms resisting colonial discourse and of conferring the status of "subject" to a female Other who is visibly marked as Muslim.

A third and last major theme emerging from our conversation about physical activity and religion is related to the challenge posed to the young Shia Muslim Canadian women in terms of combining physical activity with wearing the Hijab. About half of the participants state that the Hijab is not a barrier to physical activity in general but recognize that wearing it decreases their physical activity options and makes physical activity difficult for a number of reasons including getting hot and uncomfortable, feeling discomfort from the stares, and feeling discriminated against. Samia's narrative provides an example of some of the issues discussed by the participants:

I can't lie and say that it doesn't affect it at all. Because if I wasn't wearing the Hijab, I would probably be able to just wear a jogging suit and run on the canal. I've always wanted to jog on the canal but it was always too warm and with the Hijab, it's just, it's a killer. I mean, you'd probably sweat a lot and lose a lot of weight but... [laughs]. So, I couldn't do things, everything that I wanted to do. Uh, not because I can't but because I feel self-conscious. I mean everyone there is in swimsuits and you come wearing everything from head to toe, sitting there. Yeah, it just doesn't look right on the beach [laughs]. So there are things that I can't do. Like I said, I can't go to the gym right next door. I have to go to a gym that's 10 minutes farther because it has a women's section.

For some women, participating in physical activity while wearing the Hijab is seen as difficult while for others, physical activity and the Hijab are a good combination. One thing remains though: for most participants, the Hijab appears as a crucial part of their identity and, for some, it is a way to be brought closer to Allah. The participants' narratives are explicit about the feeling of "exposure," a sense of 
nakedness, when the Hijab is not worn. Contra the mainstream view of obligation and oppression related to the wearing of the Hijab in day to day activities, all young women express their "personal choice" in that regard, while two of them state that they wear the Hijab even though their mothers do not and one even discloses the difficulty of getting her family to accept her decision to wear the Hijab.

Most sport scholars exploring the issue of the Hijab have focused on the problems with it. For example, Sfeir (1985) suggests that despite the fact that the Quran itself says nothing about an obligation to wear a Hijab, some interpretations of the Quran are such that they limit women's physical activity participation. Guerin and colleagues (2003b) note that dressing differently from other participants (e.g., wearing a Hijab or a Shalwar Kameez) can constitute a barrier for Muslim women to engage in some forms of physical activity. In our own study, the young women do acknowledge these issues but nevertheless feel that the Hijab and physical activity need not be separated. On this, their narratives are underwritten by two very different discourses. Most of the women appropriate and subject themselves to a gendered and religious discourse dominant in certain Muslim communities where the Quran is interpreted in ways that place restrictions on women's clothing and behavior. Simultaneously, their narratives reflect a strong resistance to a dominant neo-colonial and Islamophobic discourse in Canada. A number of authors (see Nesbitt-Larking, 2006) have reported how Canada's proximity to the U.S. (in an era of homeland security, the war against terrorism and the invasion of Iraq) has meant reconfigurations of the social representations of Muslims in general and Muslim women in particular that are reflective of anti-Muslim hostility. However, within various competing gendered, racialized, and regulating (religion, academy, the media) discourses, representations of Muslim women have been unsurprisingly fixed: Muslim women are invariably seen as oppressed and stifled by their Hijab (Ahmad, 2003; Farooq, 2007). At the same time, the Hijab (and often, but not always, the women who wear it) is seen as a sign of resistance to the West (Behiery, 2009). In contrast, the young women in our study are quick to construct themselves in ways that contest the stereotypes and that explicitly speak to their desire for integration in mainstream society as fully constituted (and sufficiently exposed) subjects. Physical activity constitutes, for them, one of the ways to resist the colonial views of Islam and the Hijab. Many of the young women also appeal to a strong discourse of entitlement in the sense that they have a "right" to participate in physical activity with the Hijab on. The participants are adamant that changes need to occur so that more Muslim women can reap the benefits of physical activity. Such changes include developing sex-segregated spaces, lowering the cost of participation, and making education on (and alternative representations of) Islam and Hijabi women available to recreation providers, health educators and the public in general.

\section{Conclusions}

The objective of this article was to further our understanding of young Shia Muslim Canadian women and their constructions of physical activity in relation to gender, Islam and, the Hijab. Our results show that the participants construct physical activity mostly in terms of fitness activities that are accessible to them as Muslim women, in terms of feeling good about themselves, and in terms of losing or maintaining weight. In relation to physical activity, these participants note the lack of 
proper places for Muslim women within both Shia Muslim communities and the larger Canadian community. Finally, these participants express their attachment to an inseparable trio of religion (which takes precedence over physical activity), the Hijab (despite the difficulty it may pose for physical activity), and physical activity (as a means to become a better Muslim or to contest colonial views).

Our feminist poststructuralist stance has allowed us to go beyond what participants had to say about physical activity to explore how they said it. We can conclude that the participants locate themselves as subjects and reproduce a number of competing discourses when they construct their meanings of physical activity. For instance, they recite a discourse of entitlement to participate in sport and physical activity, but make no appeal to a discourse of gender equity (that could help them secure more opportunities within their communities or outside) and rather appropriate conventional discourses on sport and gender. Furthermore, these young women equate physical activity with feelings of self-confidence and holistic wellbeing but at the same time, they position themselves as subject within mainstream bodily discourses and construct themselves as subjects who have a negative relation to the self (i.e., subjects who desire a thinner, more beautiful body that is closer to the Western ideal). In that regard, their discussion on appearance and fear of becoming fat seems to reflect a conceptualization of the female body as an object to be "gazed" upon at least as much as an entity allowing them to experience physical activities as varied, enjoyable, and transformative technologies of the self. Finally, the young Shia Muslim Canadian women strongly resist neocolonial discourses and appeal to a progressive interpretation of the Quran where they construct themselves as modern Muslim subjects, yet they locate themselves within mainstream (i.e., conventional) religious, gendered, and heterosexualized discourses on women and physical activity.

Our feminist postcolonialist orientation has also provided us with a lens to better decipher the participants' location along the spectrum of competing discourses on feminist thought. As Mohanty (2004) suggests, mainstream feminist ideas are associated with a Western model of women's emancipation that celebrates individuality and modernity. This model presumes that diasporic women lead a constrained life based on their gender and ancestry (which is often equated to poor, uneducated, tradition-bound, domestic, and victimized) and presupposes the geographical and historical continuity of the meaning of the headscarf. In such a model, the Hijab is conceived as an obstacle to neo-colonial control and constructed as the prime symbol of women's oppression, thereby justifying the Western "civilizing mission" (Behiery, 2009). In this perspective, the decision to wear the Hijab cannot be envisaged as a personal choice and any notion of subjectivity on the part of Hijabi women must be discarded.

A very different type of feminist thought emerged from our participants' narratives. These young Shia Muslim women do not feel constrained, uneducated, tradition-bound, domestic, or victimized. They rather offer "active" resistance to the usual way in which Western discourses construct brown and/or veiled women and offer a drastically different view of "solutions" to better their lives. By considering the Hijab as an object that does not take away from their status as "subjects," these participants offer a representation of veiled women that resists the neo-colonial construction of this sign and that leads non-Others to see through an/Other cultural screen. 
The link between physical activity and the Hijab emerged from the conversations with our participants but our intent is not to promote this piece of clothing as it may at times and in many countries constitute an instrument of oppression. Nevertheless, it seems to us that rather than constituting a threat to the Western subject, the Hijab offers this subject an opportunity to be transformed (but not defined) by Otherness. We should be mindful that the recent Western preoccupation with veiled women serves to deflect our attention from the sexism and racism that pervades Canadian society, including sport and physical activity. It is our hope that the current study counters the problematic visions of the Muslim "Other" promulgated in mainstream Canadian society and forward an intersectional discourse (Baines, 2008) that allows us to understand Muslim women's refusal to choose between their right to religious freedom and their right to physical activity.

\section{References}

Ahmad, F. (2003). Still “in progress?” Methodological dilemmas, tensions, and contradictions in theorizing Muslim women. In N. Puwar \& P. Raghuram (Eds.), Women in the diaspora (pp. 43-65). New York: Oxford.

Baines, B. (2008). Must feminists support entrenchment of sex equality? Lessons from Quebec. Social Science Research Network Electronic Publishing, pp. 1-17. Retrieved 20 March 2009 from: http://papers.ssrn.com/sol3/papers.cfm?abstract_id=1275423

Basit, T.N. (1997). "I want more freedom, but not too much": British Muslim girls and the dynamism of family values. Gender and Education, 9(4), 425-439.

Behiery, V. (2009). Discours alternatifs du voile dans l'art contemporain. Sociologie et Sociétés, 41(2), 299-325.

Bhabha, H.K. (1994). The location of culture. London, New York: Routledge.

Bhopal, K. (1997). Gender, 'race' and patriarchy: A study of South Asian women. Aldershot: Ashgate.

Brah, A. (1996). Cartographies of diaspora: Contesting identities. New York: Routledge.

Butler, J. (1997). The psychic life of power: Theories in subjection. Palo Alto, CA: Stanford University Press.

Carrington, B., Chivers, T., \& Williams, T. (1987). Gender, leisure and sport: A case study of young people of South Asian descent. Leisure Studies, 6(3), 265-279.

Crawford, R. (1980). Healthism and the medicalization of everyday life. International Journal of Health Services, 10(3), 365-388.

Dagkas, S., \& Benn, T. (2006). Young Muslim women's experiences of Islam and physical education in Greece and Britain: A comparative study. Sport Education and Society, 11(1), 21-38.

De Knop, P., Theeboom, M., Van Engeland, E., Van Puymbroeck, L., De Martelaer, K., \& Wittock, H. (1995). Sport and ethnic minority youth. Journal of Comparative Physical Education and Sport, 17(1), 12-23.

De Knop, P., Theeboom, M., Wittock, H., \& DeMartelaer, K. (1996). Implications of Islam on Muslim girls' sport participation in Western Europe: Literature review and policy recommendations for sport promotion. Sport Education and Society, 1(1), 147-164.

Fanon, F. (1967). Black skin, white masks. New York: Grove Press.

Farooq, S. (2007, April 12). Media miscasting and many misunderstood Muslims. Pakistan Post - Next Generation, pp. 14.

FIFA ban on Islamic headscarf kicks Iran girls' football team out of Youth Olympics (2010, April 5). Winnipeg Free Press Online Edition. Retrieved 10 April 2010 from: http:// www.winnipegfreepress.com/sports/soccer/fifa-ban-on-islamic-headscarf-kicks-irangirls-soccer-team-out-of-youth-olympics-89927212.html 
Fleming, S. (1994). Sport and South Asian youth: The perils of 'false universalism' and stereotyping. Leisure Studies, 13(1), 159-177.

Fleming, S., \& Khan, N.M. (1994). Islam sport and masculinity: Some observations on the experiences of Pakistanis in Pakistan and Bangladeshis in Britain. In P. Duffy \& L. Dugdale (Eds.), HPER - Moving around the $21^{\text {st }}$ century (pp. 119-128). Champaign, IL: Human Kinetics.

Foucault, M. (1972). The archeology of knowledge and the discourse on language. New York: Tavistock.

Foucault, M. (1977). Discipline and punish: The birth of the prison. New York: Pantheon Books.

Gard, M., \& Wright, J. (2005). The obesity epidemic: Science, morality and ideology. London: Routledge.

George, T., \& Rail, G. (2006). Barbie meets the bindi: Discursive constructions of health among young South-Asian Canadian women. Women's Health and Urban Life, 4(2), $44-66$.

Gubrium, J.F., \& Holstein, J.A. (Eds.). (2003). Postmodern interviewing. Thousand Oaks, CA: Sage.

Guerin, B., Abdi, A., \& Guerin, P.B. (2003a). Health status of Somali refugees living in Hamilton and their experiences with the medical system. New Zealand Journal of Psychology, 32, 27-32.

Guerin, P.B., Diiriye, R.O., Corrigan, C., \& Guerin, B. (2003b). Physical activity programs for refugee Somali women: Working out in a new country. Women \& Health, 38(1), 83-99.

Hall, S. (2001). Foucault: power, knowledge and discourse. In M. Wetherell, S. Taylor, \& S. Yates (Eds.), Discourse theory and practice: A reader (pp. 72-82). London: Sage.

Handa, A. (2003). Of silk saris and mini-skirts: Girls walk the tightrope of culture. Toronto: Women's Press.

Hijab a safety risk, Quebec tae kwon do team told (2007, April 15). CTV.ca. Retrieved 25 April 2007 from CTV.ca archives.

Kaiser, B., \& Rasminsky, J.S. (2007). What does culture have to do with identity? In B. Kaiser \& J.S. Rasminsky (Eds.), Challenging behaviour in young children: Understanding, preventing and responding effectively (pp. 82-85). Toronto: Pearson Education.

Khan, S. (2002). Aversion and desire: Negotiating Muslim female identity in the diaspora. Toronto: Women's Press.

Kvale, S. (1996). InterViews: An introduction. Thousand Oaks, CA: Sage.

Loomba, A. (1998). Colonialism/postcolonialism: The new critical idiom. London: Routledge.

Lupton, D. (1992). Discourse analysis: A new methodology for understanding the ideologies of health and illness. Australian Journal of Public Health, 16, 145-150.

Markula, P. (1995). Firm but shapely, fit but sexy, strong but thin: the postmodern aerobicizing female bodies. Sociology of Sport Journal, 12(4), 424-453.

Mohanty, C. (2004). Feminism without borders: Decolonizing theory, practicing solidarity. Durham: Duke University.

More athletes barred from wearing Hijabs in Quebec (2007, April 16). The Toronto Star, p. A3.

Nakamura, Y. (2002). Beyond the hijab: Female Muslims and physical activity. Women in Sport and Physical Activity Journal, 11(1), 21-48.

Nagel, J. (1994). Constructing ethnicity: Creating and recreating identity and culture. Social Problems, 41(1), 152-176.

Nesbitt-Larking, P. (2006). Canadian Muslims: Discourses of citizenship and political entitlement. Paper presented at the annual meeting of the International Studies Association, Town \& Country Resort and Convention Center, San Diego, California, USA. Available at: http://www.allacademic.com//meta/p_mla_apa_research_citation/ 1/0/0/8/5/ pages100851/p100851-1.php 
Rail, G. (2002). Postmodernism and sport studies. In J. Maguire \& K. Young (Eds.), Perspectives in the sociology of sport (pp. 179-207). London: Elsevier.

Rail, G. (2009). Canadian youth's discursive constructions of health in the context of obesity discourse. In J. Wright \& V. Harwood (Eds.), Biopolitics and the 'obesity epidemic': Governing bodies (pp. 141-156). London: Routledge.

Rail, G., Holmes, D., \& Murray, S.J. (2010.) (in press).The politics of evidence on "domestic terrorists": Obesity discourses and their effects. Social Theory \& Health.

Reinharz, S. (1992). Feminist methods in social research. Oxford: Oxford University Press.

Roman, L. (1993). White is a color? White definition, postmodernism and anti racist pedagogy. In C. MacCarthy \& W. Critchlow (Eds.), Race, identity and representation in education (pp. 71-88). New York: Routledge.

Said, E.W. (1978). Orientalism. New York: Vintage Books.

Seibold, C. (2002). The place of theory and the development of a theoretical framework in a qualitative study. Qualitative Research Journal, 2(3), 3-15.

Sfeir, L. (1985). The status of Muslim women in sport. Conflict between cultural tradition and modernization. International Review for the Sociology of Sport, 20(4), 283-304.

Smith, L.T. (1999). Decolonizing methodologies: Research and indigenous peoples. London, New York: Z Books.

Spivak, G.C. (1988). Can the subaltern speak? In P. Williams \& L. Chrisman (Eds.), Colonial discourse and post-colonial theory: A reader (pp. 66-11). New York: Columbia University Press.

Taylor, T., \& Toohey, K. (2002). Behind the veil: Exploring the recreation needs of Muslim women. Leisure/Loisir. Journal of the Canadian Association for Leisure Studies, 26(1-2), 85-105.

Tess, K. (2006). Daughters of Islam: Family influences on Muslim young women's participation in sport. International Review for the Sociology of Sport, 41(3), 357-373.

Thompson, S.M. (1990). 'Thank the ladies for the plates': The incorporation of women into sport. Leisure Studies, 9(2), 135-143.

Tirone, S. (2000). Racism, indifference and the leisure experiences of Canadian teens. Journal of Applied Recreation and Research, 24(1-2), 89-114.

Vertinsky, P., Batth, I., \& Naidu, M. (1996). Racism in motion: Sport, physical activity and the Indo-Canadian female. Avante, 2(3), 1-23.

Walseth, K. (2006). Young Muslim women and sport: The impact of identity work. Leisure Studies, 25(1), 75-94.

Walseth, K., \& Fasting, K. (2003). Islam's view on physical activity and sport: Egyptian Women interpreting Islam. International Review for the Sociology of Sport, 38(1), 45-60.

Weedon, C. (1987). Feminist practice and poststructuralist theory. Oxford: Blackwell.

Weedon, C. (1997). Feminist practice and poststructuralist theory. Maiden, MA: Blackwell.

Weedon, C. (1999). Feminism, theory and the politics of difference. Malden, MA: Blackwell.

Williams, P., \& Chrisman, L. (Eds.). (1994). Colonial and postcolonial theory: A reader. New York: Columbia University Press.

Wray, S. (2001). Connecting physicality, gender and ethnicity: Muslim Pakistani women physical activity and health. In S. Scraton \& A. Flintoff (Eds.), Gender and Sport: A Reader. London: Routledge.

Wright, J., \& Harwood, V. (Eds.). (2009). Biopolitics and the 'obesity epidemic': Governing bodies. London: Routledge.

Yilmaz, I. (2000). Muslim law in Britain: Reflections in the socio-legal sphere and differential legal treatment. Journal of Muslim Minority Affairs, 20(2), 353-360.

Zaman, H. (1997). Islam, well-being and physical activity: Perceptions of Muslim young women. In G. Clark \& B. Humberstone (Eds.), Researching women and sport. London: Macmillan. 
Copyright of Sociology of Sport Journal is the property of Human Kinetics Publishers, Inc. and its content may not be copied or emailed to multiple sites or posted to a listserv without the copyright holder's express written permission. However, users may print, download, or email articles for individual use. 